\title{
Who is Afraid of School Choice? ${ }^{1}$
}

\author{
Andrea Diem* and Stefan C. Wolter*
}

Free choice of school and hence competition between schools in Switzerland is an interesting theme also for international comparative research, for at least two reasons: On the one hand, Switzerland is an OECD country with an extremely low percentage of private schools (just $4 \%$, compared with the OECD average of $11 \%$, OECD 2010), and there is little or no option to choose one public school in preference to another due to the fact that the public schools children attend are determined by their place of residence. On the other hand, free school choice is an ongoing political issue which features regularly in cantonal referendums. Hence, voters have expressed their views now and again - in some regions more than others - on proposed changes in policy with respect to school choice options.

This paper is motivated by three underlying research questions: Firstly, school choice options for parents can differ in content and presentation, and it is not clear whether all conceivable models would attract equal support, or opposition, from the voting public (see Bearse et al. 2009). School choice options can consist in a) legalizing private schools (a prohibition on private schools was in force in some Swiss cantons right into the 20 th century), b) providing state subsidies or funding for private schools for one and all or, alternatively, for low-income groups (with "selective" or needs-based education vouchers), or c) allowing people to choose freely between public or state schools. Since actual political propositions have often put just one single model to the vote, it is difficult to judge, even with the existing expressions of the will of the voters, whether all the models for the expansion of choice would be judged in the same way. Since no school-choice proposals have ever been put to the vote in a national referendum, we do not have the option of taking an exit poll for the whole of the country. ${ }^{2}$ Instead, the method we have cho-

Swiss Coordination Centre for Research in Education (SKBF), CH-5000 Aarau, andrea.diem@ skbf-csre.ch and stefan.wolter@skbf-csre.ch.

1 We gratefully acknowledge Maria A. Cattaneo for her support in generating the data and the survey questionnaire, and the two anonymous referees and the editor for their helpful comments and suggestions.

2 Examples for relevant exit poll analyses are Bonoli and Häusermann (2009), analyzing Swiss referendum results on the basis of VOX data (VOX analyses are polls conducted after every referendum) or Catterall and Chapleau (2003) investigating the main reasons for and against the introduction of education vouchers in the USA. 
sen for this study is a poll eliciting responses to hypothetical political propositions. This enables us at least to compare two very different models, i.e., state funding for private schools and freedom to choose between public schools. Our analysis of the will of the voters in respect of hypothetical models follows the examples set by Swiss and foreign precedents in similar issues or cases (see Sandy 1992; Belfield 2003; Brunner and Sonstelie 2003).

Secondly, this study wants to analyze heterogeneities in regard to support for and opposition to both models. Even in the presence of significant opposition or support, it is reasonable to assume that not all individuals and groups will express the same preferences. It is therefore a matter of interest to establish whether the differences reside in purely individual preferences or whether in fact specific characteristics may serve to predict differences in preference. Although an analysis of two referenda on school choice in Switzerland by Merzyn and Ursprung (2005) is available which seeks to explain the different proportions of yes-votes in individual local government areas for two different cantonal bills on the basis of differences in sociodemographic composition and political affiliations between the areas, such investigations are subject to a potential risk of ecological fallacy. That is why we have chosen to base our own analysis on individual data.

Thirdly, it is of interest to compare our study results with foreign studies on similar or identical issues, since it cannot be assumed that sociodemographic differences in preferences are expressed in the same way in all countries. Likely reasons include different educational traditions, very different prevalences of private schooling, as well as differences in the relative quality of public versus private schools.

The specific research questions are the following: What are the attitudes of Swiss voters to different models offering more freedom of choice in the educational system? Can the approval-opposition heterogeneity be explained by rational calculation of personal utility? The study uses data generated by gfs.bern research institute on behalf of the Centre for Research in Economics of Education at the University of Bern in 2007. The respondent population comprises members of the Swiss electorate aged 25 or over. The poll elicited answers to a variety of educational policy issues. ${ }^{3}$ It also generated detailed sociodemographic information about the respondent population that enables us to test our hypotheses.

The paper is structured as follows: Section 2 presents an outline of the public and private school landscape and the school choice debate in Switzerland. Section 3 presents theories and research hypotheses. Section 4 describes the data acquisition process and the database. Section 5 presents the empirical data and the final section gives the conclusions drawn from that data.

3 Published research on other educational policy issues from the same dataset are Cattaneo and Wolter (2009) and Busemeyer et al. (2011). 

in Switzerland

In Switzerland, each canton determines to a large extent its own educational policy. The cantons set forth public school curricula, determine which teaching materials are to be used, stipulate the procedure according to which students are allocated to particular public schools, decide upon the establishment of private schools, and rule over whether private schools can receive funding from the public purse.

In line with current legislation, public schools are fully funded by the state and school-age students are allocated to schools according to a strict principle, i.e.: children must attend the school in their particular catchment area. The result is a pronounced socio-geographic separation effect which is reflected in de facto school segregation (see Coradi Vellacott 2007), particularly in urban areas: privileged individuals choose an attractive, prosperous residential area in the expectation of high-quality schooling ("good" peers, good teachers, good infrastructure, etc.), and higher rents and real estate prices also prevent the less well-off from settling down in those areas (Schmidheiny 2006).

Unlike state schools, most private schools are required to obtain all of their funding from parents. In very few cantons (Basel-Landschaft, Jura, Lucerne, Zug, Bern), however, parents sending their child to a private school are reimbursed for part of the tuition. Precise figures on the costs of private school attendance are not available, but it is possible to estimate the approximate level of school tuition by looking at the sums spent by the state, since it is reasonable to assume that the costs a private school incurs in Switzerland will not be any lower. The mean cost per child per year in secondary school level I is CHF 16100 (FSO 2010a), which corresponds to about one-fifth of the annual disposable income of an average household.

The size of the private school sector during the compulsory schooling period varies greatly between the cantons. In eight cantons (Appenzell Innerrhoden, Glarus, Nidwalden, Uri, Jura, Vaud, Fribourg, Aargau), the percentage of school-age children attending non-public schools is less than one percent. In another 12 cantons, the figure ranges from 1 to 4 percent (Lucerne, Schwyz, Neuchâtel, Solothurn, Bern, Schaffhausen, Graubünden, Obwalden, Thurgau, Basel-Landschaft, Saint Gallen, Zug). From about 4 to 6 percent, the percentage in the cantons Appenzell Ausserrhoden, Vaud, Zurich and Ticino is slightly above the Swiss average. The cantons of Basel City $(10 \%)$ and Geneva $(16 \%)$ have a relatively high proportion of private school students (school year 2008/2009; FSO 2010b).

Although precise figures and data are lacking, it can be derived from the publicly available lists of private schools that the sector is fairly heterogeneous but that three types of private institutions dominate the scene: Firstly, faith-based schools (mainly Catholic), secondly, so-called alternative schools (Steiner, Montessori, etc.) and thirdly, international and bilingual schools. Whereas faith schools prioritize 
teaching religious values and principles, alternative schools use methods and teaching approaches that deviate from those employed in public schools and may differ in content as well. The hallmark of international schools is their international curriculum. These schools are designed in the first instance to cater to the needs of expatriates in a globalized world.

Five Swiss cantons have voted on "popular initiatives" concerning free school choice during the last 12 years. The new Middle School Act of the Canton of Zurich (1999), calling for freedom to choose between public schools and a state funding option for private schools in the upper-secondary school sector, was accepted with a "yes" vote of $60 \%$. The other four proposals, all of which concerning private school choice, were resoundingly rejected. The proposal in the canton of Ticino (2001) for means-tested education vouchers of CHF 2400 to CHF 6000 was rejected by a three-quarters majority $(74.1 \%)$. The counter-proposal - to restrict government subsidies to private schools to the compulsory schooling period - was rejected by an equally large majority of the voters $(72.3 \%)$. Initiatives in the canton of BaselCountry (2008) and Thurgau (2010) calling for private schools to receive funding equivalent to the average cost for state schools were opposed by $79.2 \%$ and $83.2 \%$ of voters, respectively. A counter-proposal calling for an increase in government reimbursement of the cost of private school attendance during the compulsory schooling period from the previous CHF 2000 to CHF 2500 was accepted, however (56.9\% "yes" votes, canton of Basel-Country). And finally a referendum in St. Gallen (2011) which called for free school choice (incl. private school choice) has been rejected just recently by $82.5 \%$.

\section{Free school choice: theories and research hypotheses}

Free school choice has been a political issue ever since the introduction of public schools and compulsory education laws in the 19th century. While the first conflicts were mainly fueled by ideological dispute between advocators of public lay schools and private faith-based schools, other ideologies and differences entered the debate in the 20 th century, to be joined in the post-war years by the theory that introducing market forces in this realm of the public sector might bring benefits in terms of effectiveness (school quality) and efficiency (cost of education). The hoped-for benefits of a pluralist educational system with a variety of providers and freedom of choice for customers of education, i. e., utility benefits due to freedom of choice and more effectiveness and efficiency as a result of competitive forces, are balanced on the other side by fears that competition and freedom of choice might detract from equality of opportunity and social cohesion (see e. g. Levin 2002).

The aim of this study is neither to summarize the arguments for/against free school choice, nor to re-evaluate the now numerous empirical studies on the subject, 
but rather to investigate the reasons behind political support of and opposition to more freedom of school choice.

\subsection{Theories}

Our research hypotheses in this study are mainly based on rational choice theory, which postulates that individuals primarily act in a purposeful, rational manner so as to maximize utility; this extends to include their political preferences. When making decisions, individuals weigh up the (likely) costs and benefits of various alternatives and finally choose the option that promises the highest personal advantage. The fitness of this model is supported by the observation that analyses of voting behavior have indicated that voters act so as to maximize benefit (Tedin et al. 2001; Bonoli and Häusermann 2009); moreover, similar hypotheses have been confirmed in polls investigating preferences with regard to competition-based educational reform (Belfield 2003).

Of course, school choice decisions cannot solely be ascribed to individual costbenefit rationale, but other theories or concepts can be applied to explain differences in voter preferences regarding school choice and competition.

Jarvis and Alvanides (2008) suggest applying a household resource perspective. Further insights offer approaches which consider social actions in the context of economic, cultural and social capital (Bourdieu 1983). The cultural capital plays a critical role in school choice decisions, as it depends on knowledge about the school system, information about the local school, access to relevant information about school alternatives and the ability to decipher them, and generally the ability to "work with the system" (Ball 1993; Noreisch 2007a). Social capital (networks) is also important for information search. Economic resources become especially significant, if school choice is restricted. They enable to use private schools, to move to preferred neighborhoods and to finance costs of transportation (Goldring and Phillips 2008; Byrne 2009). There is broad evidence that cultural, social and economic resources are positively associated with active school choice (Marschall 2000; Andersen 2008; Kristen 2008; Goldring and Phillips 2008; Burgess and Briggs 2010; Riedel et al. 2010; Waslander et al. 2010).

Moreover, school choice decisions are particularly important in the context of reproduction of status positions (Yoon and Gulson 2010), where cultural capital, and specifically formal education, play a central role (Raveaud and Zanten 2007; Sikkink and Emerson 2008; Byrne 2009). As suggested by the outgroup avoidance theory (Saporito 2003; Bifulco et al. 2009), privileged families pursue the objective to maintain their social status by distancing themselves from less privileged families and by joining "people like them" (Vincent et al. 2010). In fact, higher percentages of underprivileged students (blacks, immigrants, low-income, low-educated) in a local school increases the likelihood for privileged students (whites, natives, highincomes, high-educated) to opt out (Saporito 2003; Bifulco and Ladd 2007; Lauen 
2007; Noreisch 2007b; Andersen 2008; Sikkink and Emerson 2008; Li 2009; Gerdes 2010; Rangvid 2010). After all, school choice decisions may also be interpreted as the result of values and norms (Noreisch 2007a; Raveaud and Zanten 2007; Reay et al. 2007). Finally, empirical evidence shows that teachers are more likely to oppose school competition and private schools (Sandy 1992; Belfield 2003), in particular if they are unionized (Ferraiolo et al. 2004), which is in line with the insider-outsider theory (Lindbeck and Snower 1986) in labor economics.

Although there are many different theories from which hypotheses could be derived, our reading of these theories is such, that for most group characteristics of voters, they do not lead to conflicting hypotheses. Also, the nature of our data rather permits to generate first descriptive evidence about group differences in preferences for more school competition than to make clear distinctions between competing theories.

To analyze voter preferences in our study, we will distinguish between two different models proposing greater freedom of school choice: 1) state funding of private schools with public money (also known as "private school choice" in the following), and 2) the option to choose between public schools (also called "public school choice" in the rest of this paper).

\subsection{Hypotheses}

In a comparison of these two school choice options, approval rates for public school choice are likely to be higher than for private school choice: while the first reform option should be cost-neutral, the introduction of private school choice would mean that school tuition now paid by the users of private school services would have to be funded by taxpayers. Across the whole of society, the costs would remain more or less constant; however, the majority of taxpayers would face additional expenses compared with the current situation, which would be to their disadvantage. Since the proportion of private school users in Switzerland is very small at present, only a commensurately small proportion of the voters would be likely to benefit overall from the private school choice scheme (as the "small" rise in taxes would be exceeded by large savings in terms of spending on private education). This hypothesis is based on the conjecture that the proportion of private schools is currently low not because large sections of the population - in particularly those with school-age children would prefer to go private but remain in the state school system because they cannot afford private schooling. Differences in approval rates between the two school choice options may also be explained by preferences for "service public". Strong proponents of service public may reject private school choice, but not necessarily the option of choice between public schools. Thus, as in the cost-utility-approach, higher approval rates are expected for public school choice than for private school choice.

In the present situation, with no public subsidies for private schools, the decision-making scenario with regard to choosing private schooling is as follows: before 
an individual opts for private schooling, the additional benefit of private schooling versus public schooling must be larger than the additional individual expense (school tuition) of private school attendance. In a scenario where private school choice is publicly funded, all those who would benefit more from private schooling than public school attendance would switch to private schools. Assuming for a moment that all the people would calculate the same net benefit of private versus public schooling, then the ones that would benefit the most from the public subsidy for private schools would be those who prior to that did not have the means to pay the tuition fees. However, if the individual preferences for private versus public schooling would not depend on the financing schemes, then the ones profiting the most from an introduction of public subsidies would be the ones who already send their children to private schools. As these people tend to be the ones with higher income, the support for the change would be backed up by higher incomes and vice versa. Because of the substantial financial repercussions of changes in the financing of the school system most of the theoretical and empirical studies in existence analyze the impact of disposable household income as a key predictor of preference for or opposition to a greater freedom of school choice. The empirical as well as the theoretical results are very mixed, however. The positive correlation between income and support for greater freedom of choice postulated in earlier theoretical studies (see e. g. Epple and Romano 1998) is backed up in some empirical studies, while others find quite the opposite. Belfield (2003) finds no income effects that explain support for or resistance against school competition in the UK. Results of a United States exit poll (Catterall and Chapleau 2003) indicate that individuals of low socioeconomic status are more likely to oppose education vouchers than those on a high income. Similarly, a Japanese study (Oshio et al. 2010) shows that income has a positive impact on approval of greater school choice and Merzyn and Ursprung (2005) found the lowest approval rates for freedom of choice in middle-income communities. On the other hand, empirical evidence of a negative correlation between income and support for free school choice is available in slightly older United States studies (Sandy 1992; Lee and Croninger 1994), and in Brunner and Sonstelie's paper (2003). All of the studies differed significantly in time and geography, however, and most of them also differed in regard to the specific research question and respondent population. It is therefore not clear from the outset, whether we should expect a negative or positive correlation between income and approval rates if one does not consider other aspects of the school choice simultaneously.

A crucial determinant of voting behavior (in a static model) is that public funding of private schooling would not only reduce the price for private school attendance but also raise taxes. Hence, not only those citizens would vote against the new "private school choice" model who rate the utility of state school attendance higher than that of private schooling, but also the citizens whose utility gain from private schooling would be less than the utility loss from the tax hike. Voters who 
are currently sending their children to a private school or expect to do so in the future would opt for the new model if the savings on private school fees were to be higher than the higher tax burden arising from the change of model.

In the longer run (dynamic model), one factor to consider is that more freedom of school choice might result in more heterogeneity at private schools, because an increasing number of low-income individuals would be able to afford them. A possible consequence of the likely change in composition of the student population is - in line with the outgroup avoidance and also the social reproduction theory that some people would oppose more school choice even if it would benefit them financially; they are prepared to pay the price of limited access to private schools because they see additional benefits in the current composition of the student population at private schools that offset the additional costs.

Applying these combined predictions to the various socioeconomic groups, the hypothesis we set up for Switzerland is that members of lower-income groups would be more likely to opt for private school choice than respondents from the higher income classes because they can currently not afford privately paid education and the increase of taxes would not affect them much because of their low incomes. Middle and higher income groups not intending to send their children to private schools (and those with no children), on the other side, will be wary of a loss of utility as a result of the higher tax burden and will therefore oppose the change. This opposition will be reinforced by those members of middle and higher income groups intending to send or already sending their children to a private school, as they will be apprehensive of a change in the composition of the student population. They fear that this would reduce their benefit from private schooling more than the monetary advantage of this solution would raise their benefit.

The decision-making scenario as regards choosing between public schools differs slightly, but not radically, from the private school scenario. In regard to expectations of different income groups, opposition to the proposed model would again be expected from higher income groups who can already afford free school choice among public schools by moving to the desired residential area and would fear changes in the school composition. Low income individuals on the other side, who, due to the positive correlation between the quality of schools and higher rents and housing prices (see e.g. Brasington and Haurin 2006; Dougherty et al. 2009; Fack and Grenet 2010; Machin and Salvanes 2010) are restricted in their options, would be more likely to support school choice between public schools.

Based on the existing literature, we would expect a significantly higher opposition to both proposals among teachers. More than $95 \%$ of them work for public schools and as such are not exposed to any appreciable competition at the moment, neither from private schools nor from neighboring public schools.

Applying the rationale choice approach again, we would expect individuals without children or with children who are no longer of school age to vote for the 
private school choice model only if they rate the quality of public schooling to be so poor that expansion of the private school sector would be to the benefit of the whole of society, in fact to the extent of justifying the increased taxes. The latter is unlikely given the general belief in the quality of public schooling in Switzerland. Therefore we expect greater resistance to private school choice among all those who have no children at school-age.

Also strictly in line with a rational choice approach, we can expect that inhabitants of rural areas see no benefit in an increased school choice as in sparsely populated areas the density of alternative schools is very low. We further assume that the proportion of private schools in a canton is negatively correlated with the approval for private school choice, as an already high share would induce higher costs and thus a higher tax burden. Furthermore, voters' ratings of current school quality in the state school system are expected to display a negative correlation with approval of more school choice in both proposals. The more citizens are satisfied with the current school quality, the less reasons they have to vote for any change of the educational system.

Finally, and independently of preferences regarding the education system, it is also reasonable to expect that groups who are for cultural or ideological reasons strong advocators of "service public" would be likely to oppose the private school choice reform. We would therefore expect to see differences between language regions (Italian and French linguistic areas have demonstrated a stronger preference for the public sector than the German-speaking area in previous political proposals) and based on personal political convictions (left-right).

\section{Data acquisition and database}

\subsection{Data acquisition}

The data evaluated in this paper were generated by an opinion poll conducted by the gfs.bern research institute on behalf of the Centre for Research in Economics of Education at the University of Bern. ${ }^{4}$ The poll took place in 2007 using a webcati ${ }^{5}$ system. The study population comprised members of the Swiss voters aged 25 or over. $^{6}$

4 The authors wish to thank Maria A. Cattaneo for her support in generating the data and the survey questionnaire.

5 Webcati is a computer assisted telephone interview which is based on web-solutions (decentralized telephone laboratories connected to an intranet).

6 This age restriction was chosen because the participation rate of young people is generally low both in interviews and in elections. We do not, however, expect that our findings would change substantially if the 18-24 year olds had been included. In a previous referendum (unified health insurance, 2007) which dealt with similar questions about market competition versus government control, the approval rates of the 18-24 year olds did not significantly differ from the ones of the older population (VOX data, own calculations). 
The sample selection was based on stratified randomization. ${ }^{7} 2025$ valid interviews were conducted in total, corresponding to a response rate of $28 \%{ }^{8}$

The poll elicited information on preferences for free school choice on the basis of two questions, thereby enabling nuanced analysis of two key dimensions of free school choice: freedom to choose between different state schools (public school choice), and public subsidies for private schools (private school choice).

The questions were worded thus:

- "What is your stance on calls for private schools to receive public funding?"

- "What is your stance on calls for parents to be able to choose freely between different public schools for their children?"

The questions were designed to resemble existing initiative texts in ongoing or past referenda on the issue of private school choice. At the same time, the amount of funding or type of individual funding (e. g., only selective, i. e. means-based funding) was left relatively open in order to incorporate the broadest possible spectrum of potential extension of options between private and public schools. The question about choice between state schools did not restrict choice to specific stages of education, as was done in some of the real-life political proposals, again in order to embrace a wide range of increased options.

Reply options per question were "very much in favor", "somewhat in favor", "somewhat against" and "very much against". In order to simulate the outcome in a referendum, we create binary dummy variables as outcome variables that take the value 1 if the reply categories are "very much" or "somewhat in favor" and 0 for the other reply categories.

\subsection{Descriptive results}

Figure 1 shows the proportion of respondents in favor of/opposed to free school choice. Freedom to choose between public and private schools, i. e. the call for state subsidies for private schools, is rejected by almost three-quarters of the respondents.

$7 \quad$ The sample was stratified by language region, i.e. German-speaking, French-speaking and Italian-speaking Switzerland. Households and target persons in the household were selected by randomization. The population for the sampling was the Swiss telephone directory. To obtain a representative picture of the total study population, the number of interviews was restricted through the use of upper limits for gender, age (25-39, 40-64, 65 and over), level of education (no lower-secondary qualifications, lower-secondary education, upper-secondary vocational education, upper-secondary general education, tertiary-level B professional education and training, tertiary-level A education) and marital status (single, married, widowed, divorced). Therefore the sample is not purely random and the use of inferential statistics has to be seen within these limits.

8 The gross sample contained 10233 original addresses. Deduction of sample-neutral omissions (mistakes in original addresses and overrepresentation problems) resulted in a net sample of 7214 people.

9 We also conducted ordered probit analysis using all four reply categories. The results remain very much the same. 
Only $27 \%$ said they were in favor of having the state subsidize private education. ${ }^{10}$ The approval rates for private school choice are highly congruent with the results of past referenda, which confirms the validity of this poll. In the canton of Ticino, $26 \%$ of participants voted for a similar proposal (2001), while the yes vote in the canton of Basel-Country (2008) was $21 \%$.

The situation presents itself very differently as to whether there should be freedom to choose between state schools. This option attracted a large majority, with $64 \%$ saying they were "somewhat" or "very much" in favor. ${ }^{11}$

These results serve to back up the conjecture that members of the voters have a nuanced view of different forms of free school choice.

Figure 1 Approval rates for free school choice

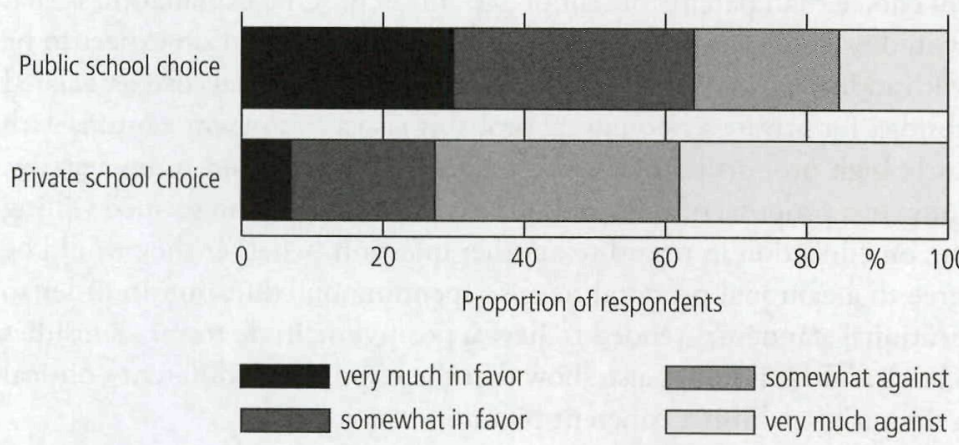

10 Non-response analyses for the two questions analyzed here show no significant over- or underrepresentation for observable respondent characteristics.

11 The estimated approval rates may show some bias as, in real life, not all of those eligible to vote are equally likely to take part in referenda. To take this into account, weighted approval rates were calculated. The weightings were calculated on the basis of average election participation (VOX analyses, 2005-2007), with gender, age, education and language region factored in. The approval rates "corrected" for selectivity barely differ from their unweighted counterparts, with "yes" proportions of $28 \%$ and $64 \%$, respectively. In other words, there are practically no differences between weighted and unweighted responses. 


\section{Empirical calculations}

Two different analyses are conducted in the following. A probit analysis is used to test affirmative responses $(0 / 1)$ to each of the two questions, i. e. private school choice and public school choice. ${ }^{12}$

\subsection{Private school choice (public funding for private schools)}

Table 1 gives the results of regression analysis on private school choice. Model 1 is the basic model. Model 2 has attitude variables added and Model 3 includes characteristics from external data.

The findings show that the income has a significant impact on school choice preferences. Individuals with higher household incomes are less likely to be in favor of private school choice than low-income individuals. ${ }^{13,14}$ Rational choice also comes into play in regard to other individual characteristics. Parents who do not have school-age children (any longer) have a much more negative attitude towards private school choice than parents of school-age children. One explanation is that the former would no longer benefit from the proposed reform but do expect to be confronted with additional costs (higher taxes). The likely additional costs associated with state subsidies for private schooling are probably also a reason why cantons with an already fairly high proportion of private school attendance tend to be negative in their response to a proposal of this kind. Conversely, people who seemed willing to spend more on education in regard to another question (whether they would be willing to agree to a cantonal proposal to raise spending on education in order to improve educational standards) tended to have a positive attitude toward subsidies for private schools. These findings also show that the responses to different political questions in the survey exhibit a coherent picture.

12 Our presentation of empirical results leaves out a number of independent variables in the models that have shown no significance in any specification. Rather surprisingly, one of those was the subjective opinion of current school quality. This aspect is relevant only in particular specifications if it is analyzed in interaction with family status. Parents of school-age children (and people with no children) tend to be stronger in their support of public school choice if they are unhappy with public schools. Other variables such as the size of household (number of adults and children), social origin or cantonal differences in terms of female paid employment, the percentage of baccalaureate school graduates and cantonal income are insignificant in all models. The percentage of Catholics in the residential population in 1900 (see hypothesis by West and Wössmann 2010) correlates negatively in some models with the support for state school choice (the authors wish to thank Mr. Silvan Müggler for processing these data).

13 The reference category is individuals with a monthly household income of CHF 3000-5000. The reason for not choosing the subset with a household income below CHF 3000 as a reference category is that very few families have such a low income: among people with school-age children, just $3.5 \%$ ( 14 respondents) had a household income below CHF 3000 . The estimates for this category are therefore associated with greater measurement uncertainty.

14 Models which include interaction terms between income and education show that income is only significant for high-educated individuals. This finding is in line with the outgroup avoidance theory which posits segregation efforts of the privileged classes. 
Table 1

Private school choice

\begin{tabular}{|c|c|c|c|}
\hline & Model 1 & Model 2 & Model 3 \\
\hline \multirow{2}{*}{ Female } & 0.034 & 0.030 & 0.029 \\
\hline & $(0.023)$ & $(0.022)$ & $(0.022)$ \\
\hline \multirow[t]{2}{*}{ Age 40-64 } & 0.043 & $0.048^{*}$ & $0.048^{*}$ \\
\hline & $(0.025)$ & $(0.024)$ & $(0.024)$ \\
\hline \multirow[t]{2}{*}{ Age $65+$} & 0.079 & 0.082 & 0.079 \\
\hline & $(0.047)$ & $(0.047)$ & $(0.046)$ \\
\hline \multirow[t]{2}{*}{ Household income below CHF 3000} & -0.033 & -0.032 & -0.030 \\
\hline & $(0.037)$ & $(0.037)$ & $(0.038)$ \\
\hline \multirow[t]{2}{*}{ Household income of CHF 5000-7000 } & $-0.075^{* *}$ & $-0.075^{* *}$ & $-0.076^{* *}$ \\
\hline & $(0.026)$ & $(0.026)$ & $(0.027)$ \\
\hline \multirow[t]{2}{*}{ Household income of CHF 7000-9000 } & -0.054 & -0.055 & -0.055 \\
\hline & (0.039) & $(0.040)$ & $(0.039)$ \\
\hline \multirow[t]{2}{*}{ Household income above CHF 9000} & $-0.096^{\star *}$ & $-0.098^{* *}$ & $-0.097^{* *}$ \\
\hline & $(0.034)$ & $(0.034)$ & $(0.034)$ \\
\hline \multirow[t]{2}{*}{ Teacher training qualification } & $-0.132^{\star *}$ & $-0.135^{* *}$ & $-0.131^{* *}$ \\
\hline & $(0.049)$ & $(0.047)$ & $(0.046)$ \\
\hline \multirow[t]{2}{*}{ Upper-secondary education } & -0.046 & -0.048 & -0.045 \\
\hline & $(0.030)$ & $(0.026)$ & $(0.025)$ \\
\hline \multirow[t]{2}{*}{ Lower-secondary education } & -0.041 & -0.042 & -0.044 \\
\hline & $(0.028)$ & $(0.026)$ & $(0.025)$ \\
\hline \multirow[t]{2}{*}{ Children at school-age } & $0.079^{* *}$ & $0.075^{* *}$ & $0.075^{* *}$ \\
\hline & $(0.025)$ & $(0.026)$ & $(0.027)$ \\
\hline \multirow[t]{2}{*}{ No children } & 0.018 & 0.022 & 0.021 \\
\hline & $(0.028)$ & $(0.029)$ & $(0.030)$ \\
\hline \multirow[t]{2}{*}{ Homeowner } & 0.046 & $0.049^{*}$ & $0.049^{*}$ \\
\hline & $(0.025)$ & $(0.025)$ & $(0.025)$ \\
\hline \multirow[t]{2}{*}{ Rural community } & -0.047 & -0.046 & -0.052 \\
\hline & $(0.035)$ & $(0.035)$ & $(0.036)$ \\
\hline \multirow[t]{2}{*}{ Small/medium center of population } & -0.032 & -0.032 & $-0.056^{*}$ \\
\hline & $(0.029)$ & $(0.029)$ & $(0.024)$ \\
\hline \multirow[t]{2}{*}{ French-speaking region } & $-0.120^{* *}$ & $-0.123^{* *}$ & $-0.124^{* *}$ \\
\hline & $(0.024)$ & $(0.023)$ & $(0.021)$ \\
\hline \multirow[t]{2}{*}{ Italian-speaking region } & -0.035 & -0.033 & -0.016 \\
\hline & $(0.038)$ & $(0.039)$ & $(0.050)$ \\
\hline \multirow[t]{2}{*}{ Political center } & & 0.034 & 0.034 \\
\hline & & $(0.037)$ & $(0.036)$ \\
\hline \multirow[t]{2}{*}{ Political right } & & 0.047 & 0.051 \\
\hline & & $(0.037)$ & $(0.036)$ \\
\hline
\end{tabular}

Continuation of Table 1 on the following page. 
Continuation of Table 1.

\begin{tabular}{lccc}
\hline & Model 1 & Model 2 & Model 3 \\
\hline Political affiliation missing & 0.044 & 0.041 \\
& & $(0.052)$ & $(0.051)$ \\
For increased spendings on education & $0.058^{*}$ & $0.059^{*}$ \\
& & $(0.024)$ & $(0.024)$ \\
Proportion of foreigners in place of residence & & $0.003^{*}$ \\
Proportion of (non-subsidized) private schools & & $(0.001)$ \\
& & & $-0.010^{* *}$ \\
Pseudo R-squared & 0.029 & 0.032 & $(0.003)$ \\
Model chi-square & 406.191 & 841.032 & 1395.113 \\
N & 1637 & 1637 & 1637 \\
\hline
\end{tabular}

Probit regression: marginal effects. Robust standard errors in parentheses. Cluster analysis for cantons. ${ }^{*} p<0.05,{ }^{* *} p<0.01$.

Reference person is male, aged 25-39, has a household income of 3000-5000 CHF, tertiary education, children but not at school age, lives in a large city center in German speaking Switzerland and is politically left oriented.

The importance of the quality of the educational system can account for the higher approval rates among homeowners and residents of communities with a high proportion of non-Swiss inhabitants. The former probably expect housing prices to rise in their area as a result of more private schools, and the latter welcome the enhanced range of options in the hope of sidestepping public schools with a high proportion of foreign students. The higher disapproval rates in smaller centers of population may be attributable - as hypothesized - to the fact that voters in these communities do not expect options in their geographical vicinity to improve, but would have to share the increased cantonal spending on education.

Another observation is that qualified teachers have a distinctly higher aversion to private school choice. Their oppositional attitude is explained by the fact that these professions are affected in a very immediate way by changes in the school system. The fact that those employed in education tend to be disinclined to vote for competition-enhancing reforms has been observed in past studies (see Sandy 1992 or Belfield 2003).

Finally, evidence of the postulated correlation with the language region is manifest in that inhabitants of French-speaking Switzerland, with its different understanding of the role of the state («service public») as compared with the Germanspeaking region, are very negative in their response to the proposal. Inhabitants of 
the canton of Ticino, however, do not differ in overall approval rates compared to the respondents in German-speaking Switzerland. ${ }^{15}$

Overall, political convictions seem to have no influence on support or opposition, i. e. there is no evidence of a classical left-right divide reflecting more or less competition. ${ }^{16}$

\subsection{Public school choice (free choice between public schools)}

The results for the factors modeling preferences for free school choice between public schools are presented in Table 2. Again, the findings show that the household income is negatively correlated with a support for the freedom to choose between public schools. People with a monthly income above CHF 7000 tend to be against the proposed reform compared to the reference income group. ${ }^{17}$ Our hypotheses that economically privileged groups worry that freedom to choose between public schools would result in more heterogeneous student populations and hence contribute to a lowering of educational quality in their local school see confirmation in this result. ${ }^{18}$ Conversely, for disadvantaged sectors of the population with low incomes who potentially have to contend with poorer-quality schools now, the prospective benefit of being able to attend high-quality schools in the future is the overriding factor.

Structural conditions are another key predictor of school choice preferences. Approval rates in rural areas and small and medium-sized centers of population are much lower than in larger centers of population. This result confirms our expectations: since the freedom to choose between public schools would increase options no more than minimally, it is associated with a lesser practical benefit than in larger urban communities with multiple schools within short distances of each other. The higher preference for free school choice in large centers of population might additionally be reinforced by the fact that segregation is greater here than in small communities, with a correspondingly greater need for free school choice.

As with private school choice, individuals with a teaching qualification are much less likely to approve of more choice than individuals with a different professional background.

15 Further analysis including interaction terms with political preferences reveal that inhabitants of the Ticino who see themselves on the left and right side of the political spectrum are more likely to reject the proposal than inhabitants of the German-speaking region. The contrary is true for the political center: They are more likely to approve the proposal of private school choice. This finding can be explained by the fact that the majority of private schools in Ticino are catholic schools which are likely to be supported by the members of the catholic center party (PPD), dominating the political center in Ticino.

16 Yet as already indicated, significant differences in political preferences are found for the special case of Italian-speaking Switzerland.

17 The fact that people with household incomes below CHF 3000 are against the free choice of public school model significantly more frequently than people in the CHF 3000-5000 income bracket is probably due to the small sample size of families in this lowest income category. Again, the negative effect of income is especially pronounced for high-educated individuals. 
Table 2

Public school choice

\begin{tabular}{|c|c|c|c|}
\hline & Model 1 & Model 2 & Model 3 \\
\hline \multirow[t]{2}{*}{ Female } & $0.119^{* *}$ & $0.117^{* *}$ & $0.116^{* *}$ \\
\hline & $(0.029)$ & $(0.028)$ & $(0.028)$ \\
\hline \multirow[t]{2}{*}{ Age 40-64 } & $-0.062^{*}$ & $-0.059^{*}$ & $-0.059^{*}$ \\
\hline & $(0.029)$ & $(0.028)$ & $(0.028)$ \\
\hline \multirow[t]{2}{*}{ Age $65+$} & -0.052 & -0.045 & -0.046 \\
\hline & $(0.030)$ & $(0.030)$ & $(0.030)$ \\
\hline \multirow[t]{2}{*}{ Household income below CHF 3000} & -0.077 & -0.075 & -0.074 \\
\hline & $(0.080)$ & $(0.079)$ & $(0.079)$ \\
\hline \multirow[t]{2}{*}{ Household income of CHF 5000-7000 } & -0.031 & -0.028 & -0.029 \\
\hline & $(0.034)$ & $(0.033)$ & $(0.034)$ \\
\hline \multirow[t]{2}{*}{ Household income of CHF 7000-9000 } & $-0.059^{*}$ & $-0.056^{*}$ & $-0.055^{*}$ \\
\hline & $(0.026)$ & $(0.026)$ & $(0.026)$ \\
\hline \multirow[t]{2}{*}{ Household income above CHF 9000} & $-0.063^{*}$ & $-0.063^{*}$ & $-0.063^{*}$ \\
\hline & $(0.026)$ & $(0.025)$ & $(0.026)$ \\
\hline \multirow[t]{2}{*}{ Teacher training qualification } & $-0.206^{* *}$ & $-0.210^{* *}$ & $-0.207^{\star *}$ \\
\hline & $(0.069)$ & $(0.071)$ & $(0.072)$ \\
\hline \multirow[t]{2}{*}{ Upper-secondary education } & 0.013 & 0.017 & 0.018 \\
\hline & $(0.034)$ & $(0.034)$ & $(0.034)$ \\
\hline \multirow[t]{2}{*}{ Lower-secondary education } & -0.034 & -0.030 & -0.031 \\
\hline & $(0.040)$ & $(0.040)$ & $(0.041)$ \\
\hline \multirow[t]{2}{*}{ Children at school-age } & 0.040 & 0.036 & 0.037 \\
\hline & $(0.023)$ & $(0.025)$ & $(0.025)$ \\
\hline \multirow[t]{2}{*}{ No children } & $0.071^{* *}$ & $0.071^{* *}$ & $0.071^{* *}$ \\
\hline & $(0.027)$ & $(0.026)$ & $(0.026)$ \\
\hline \multirow[t]{2}{*}{ Homeowner } & 0.002 & 0.007 & 0.007 \\
\hline & $(0.025)$ & $(0.027)$ & $(0.027)$ \\
\hline \multirow[t]{2}{*}{ Rural community } & $-0.065^{* *}$ & $-0.060^{*}$ & -0.059 \\
\hline & $(0.024)$ & $(0.024)$ & $(0.032)$ \\
\hline \multirow[t]{2}{*}{ Small/medium center of population } & $-0.071^{\star *}$ & $-0.068^{\star \star}$ & $-0.078^{* *}$ \\
\hline & $(0.025)$ & $(0.025)$ & $(0.028)$ \\
\hline \multirow[t]{2}{*}{ French-speaking region } & -0.033 & -0.038 & -0.041 \\
\hline & $(0.023)$ & $(0.024)$ & $(0.024)$ \\
\hline \multirow[t]{2}{*}{ Italian-speaking region } & $0.142^{* *}$ & $0.138^{* *}$ & $0.143^{* *}$ \\
\hline & $(0.024)$ & $(0.022)$ & $(0.024)$ \\
\hline \multirow[t]{2}{*}{ Political center } & & -0.031 & -0.032 \\
\hline & & $(0.036)$ & $(0.037)$ \\
\hline \multirow[t]{2}{*}{ Political right } & & 0.009 & 0.010 \\
\hline & & $(0.048)$ & $(0.049)$ \\
\hline
\end{tabular}

Continuation of Table 2 on the following page. 
Continuation of Table 2.

\begin{tabular}{|c|c|c|c|}
\hline & Model 1 & Model 2 & Model 3 \\
\hline \multirow[t]{2}{*}{ Political affiliation missing } & & 0.018 & 0.017 \\
\hline & & $(0.028)$ & $(0.029)$ \\
\hline \multirow[t]{2}{*}{ For increased spendings on education } & & 0.046 & 0.047 \\
\hline & & $(0.027)$ & $(0.027)$ \\
\hline \multirow[t]{2}{*}{ Proportion of foreigners in place of residence } & & & 0.002 \\
\hline & & & $(0.002)$ \\
\hline \multirow[t]{2}{*}{ Proportion of (non-subsidized) private schools } & & & -0.004 \\
\hline & & & $(0.003)$ \\
\hline Pseudo R-squared & 0.030 & 0.032 & 0.033 \\
\hline Model chi-square & 514.363 & 1681.309 & 1969.705 \\
\hline N & 1612 & 1612 & 1612 \\
\hline
\end{tabular}

Probit regression: marginal effects. Robust standard errors in parentheses. Cluster analysis for cantons. ${ }^{*} p<0.05,{ }^{* *} p<0.01$.

Reference person is male, aged 25-39, has a household income of 3000-5000 CHF, tertiary education, children but not at school age, lives in a large city center in German speaking Switzerland and is politically left oriented.

People with/without school-age children do not differ significantly. This is not surprising given the cost-neutrality of this political decision (unlike the proposal for subsidies for private schools). The results do show, however, that respondents with non-school-age children are more likely to be opposed to school choice than people who have no children at all. This opposition can be interpreted as conservatism toward educational reform, in that individuals whose children have completed their schooling consider the system they know to be the right one for future generations as well.

Men are more inclined to oppose free school choice than women. Language area-related differences are in evidence too: approval rates for free public school choice are significantly lower in the French- and German-speaking parts of Switzerland than in the Italian-speaking region.

As with the private school choice proposal, political convictions are again irrelevant in predicting voting preferences on this issue. 


\section{Conclusions}

On the basis of survey data, differentiated data have been obtained for the first time on attitudes of the Swiss voters to two different models for more freedom to choose between schools. The results show, firstly, that voters differentiate clearly between different forms of school choice. While the majority (74\%) opposes greater state funding of private schools (similarly to education vouchers), the aim of which would be to enable more freedom of choice between state and private schools, a clear majority $(64 \%)$ said they were in favor of a freedom to choose between public schools.

Secondly, the results show that individuals form their preferences in a rational manner to maximize their own personal advantage. People who see greater personal benefit in more school choice will be more likely to support both proposals and vice versa. Hence, high-income individuals who can now avail themselves of a free school choice by means of private school attendance or relocation to another area are more strongly opposed than low-income individuals. Benefit-maximizing behavior also applies with regard to family situation (school-age children) and place of residence. Inhabitants of small to median centers, unlikely to benefit meaningfully from either proposal, are more negative in their attitude to both proposals. Individuals with a teaching qualification significantly more frequently oppose any increase in freedom of choice as they fear more competition in their daily professional life.

Thirdly, the findings suggest that historical and cultural factors co-determine support for or opposition to more school choice. There are marked differences between the language regions which can be attributed to differences in the perceived role of the state but also the history of private schooling. However, individual political convictions (left-right divide), level of education, and perceived quality of the public school system have no major impact on their preferences.

It is worth highlighting that the results need to be interpreted against the background of the current Swiss educational system, in which the prevalence of private schools is extremely low, and the majority of the population is satisfied with the quality of the public educational system, but there is no freedom to choose between state schools in almost any canton (at least as far as the compulsory stage of schooling is concerned). Hence, the empirical data are not directly generalizable to other countries (or periods in time) but are at the same time interesting as they add evidence about a country that differs greatly in regard to the educational system (state and private schools and their relative status and quality), population socio-demographics, and cultural preferences from the countries for which evidence was available so far. Conflicting empirical results about the factors influencing the support for or the opposition to school choice should therefore be interpreted as an evidence that the starting position matters at least as much as generalizable differences in preferences between different socio-demographic groups. 
Future research could explore further, whether the attitudes towards school choice differ by funding schemes and by different school levels.

\section{References}

Andersen, Simon C. 2008. Private Schools and the Parents that Choose Them: Empirical Evidence from the Danish School Voucher System. Scandinavian Political Studies 31(1): 44-68.

Ball, Stephen J. 1993. Education Markets, Choice and Social Class: The Market as a Class Strategy in the UK and the USA. British Journal of Sociology of Education 14(1): 3-19.

Bearse, Peter, Buly A. Cardak, Gerhard Glomm, and B. Ravikumar. 2009. Why Do Education Vouchers Fail? CAEPR Working Paper 014-2009. Indiana University, http://iub.edu/ caepr/RePEc/ PDF/2009/CAEPR2009-014.pdf (15.9.2010).

Belfield, Clive R. 2003. Political Preferences and the Privatization of Education: Evidence from the UK. Education Economics 11(2): 155-168.

Bifulco, Robert, and Helen F. Ladd. 2007. School Choice, Racial Segregation, and Test-Score Gaps: Evidence from North Carolina's Charter School Program. Journal of Policy Analysis and Management 26(1): 31-56.

Bifulco, Robert, Helen F. Ladd, and Stephen L. Ross. 2009. Public School Choice and Integration Evidence from Durham, North Carolina. Social Science Research 38(1): 71-85.

Bonoli, Giuliano, and Silja Häusermann. 2009. Who Wants What from the Welfare State? Socio-structural Cleavages in Distributional Politics: Evidence from Swiss Referendum Votes. European Societies 11(2): 211-232.

Bourdieu, Pierre. 1983. Ökonomisches Kapital, kulturelles Kapital, soziales Kapital. Pp. 183-198 in Soziale Ungleichheiten. Soziale Welt, Sonderband 2, edited by Reinhard Kreckel. Göttingen: Otto Schartz \& Co.

Brasington, David, and Donald R. Haurin. 2006. Educational Outcomes and House Values: A Test of the Value Added Approach. Journal of Regional Science 46(2): 245-268.

Brunner, Eric, and Jon Sonstelie. 2003. Homeowners, Property Values, and the Political Economy of the School Voucher. Journal of Urban Economics 54(2): 239-257.

Burgess, Simon, and Adam Briggs. 2010. School Assignment, School Choice and Social Mobility. Economics of Education Review 29(4): 639-649.

Busemeyer, Marius R., M. Alejandra Cattaneo, and Stefan C. Wolter. 2011. Individual Policy Preferences for Vocational versus Academic Education: Micro Level Evidence for the Case of Switzerland. Journal of European Social Policy 21(3): 253-273.

Byrne, Bridget. 2009. Not Just Class: Towards an Understanding of the Whiteness of Middle-class Schooling Choice. Ethnic and Racial Studies 32(3): 424-441.

Cattaneo, M. Alejandra, and Stefan C. Wolter. 2009. Are the Elderly a Threat to Educational Expenditures? European Journal of Political Economy 25(2): 225-236.

Catterall, James S., and Richard Chapleau. 2003. Voting on Vouchers: A Socio-political Analysis of California Proposition 38, Fall 2000. Journal of Education Finance 29(1): 25-47.

Coradi Vellacott, Maja. 2007. Bildungschancen Jugendlicher in der Schweiz: Eine Untersuchung familiärer, schulischer und sozial-räumlicher Einflüsse auf Leistungsunterschiede am Ende der obligatorischen Schulzeit. Zurich: Rüegger.

Dougherty, Jack, Jeffrey Harrelson, Laura Maloney, Drew Murphy, Russell Smith, Michael Snow, and Diane Zannoni. 2009. School Choice in Suburbia: Test Scores, Race, and Housing Markets. American Journal of Education 115(4): 523-548. 
Epple, Dennis, and Richard E. Romano. 1998. Competition between Private and Public Schools, Vouchers, and Peer-Group Effects. American Economic Review 88(1): 33-62.

Fack, Gabrielle, and Julien Grenet. 2010. When Do Better Schools Raise Housing Prices? Evidence from Paris Public and Private Schools. Journal of Public Economics 94(1-2): 59-77.

Ferraiolo, Kathleen, Frederick Hess, Robert Maranto, and Scott Milliman. 2004. Teachers' Attitudes and the Success of School Choice. Policy Studies Journal 32(2): 209-224.

FSO (Swiss Federal Statistical Office). 2010a. Öffentliche Bildungsausgaben 2007. Neuchâtel: FSO.

FSO (Swiss Federal Statistical Office). 2010b. Obligatorische Schule: Schülerzahlen und Klassengrössen (je-d-15.02.01.02.01). Statistisches Lexikon der Schweiz. Neuchâtel: FSO, http://www.bfs.admin. $\mathrm{ch} / \mathrm{bfs} /$ portal/de/index/inforhek/lexikon/lex/0.topic.1.html (21.12.2010).

Gerdes, Christer. 2010. Does Immigration Induce "Native Flight" from Public Schools? Evidence from a Large Scale Voucher Program. IZA Discussion Paper 4788. Institute for the Study of Labor (IZA), Bonn.

Goldring, Ellen B., and Kristie J.R. Phillips. 2008. Parent Preferences and Parent Choices: The PublicPrivate Decision about School Choice. Journal of Education Policy 23(3): 209-230.

Jarvis, Helen, and Seraphim Alvanides. 2008. School Choice from a Household Resource Perspective: Preliminary Findings from a North of England Case Study. Community, Work \& Family 11(4): 385-403.

Kristen, Cornelia. 2008. Primary School Choice and Ethnic School Segregation in German Elementary Schools. European Sociological Review 24(4): 495-510.

Lauen, Douglas Lee. 2007. Contextual Explanations of School Choice. Sociology of Education 80(3): 179-209.

Lee, Valerie E., and Robert G. Croninger. 1994. Parental Choice of Schools and Social Stratification in Education: The Paradox of Detroit. Educational Evaluation and Policy Analysis 16(4): 434-457.

Levin, Henry M. 2002. A Comprehensive Framework for Evaluating Educational Vouchers. Educational Evaluation and Policy Analysis 24(3): 159-174.

Li, Mingliang. 2009. Is There "White Flight" into Private Schools? New Evidence from High School and beyond. Economics of Education Review 28(3): 382-392.

Lindbeck, Assar, and Dennis J. Snower. 1986. Wage Setting, Unemployment, and Insider-Outsider Relations. American Economic Review 76(2): 235-239.

Machin, Stephen, and Kjell G. Salvanes. 2010. Valuing School Quality via a School Choice Reform. IZA Discussion Papers 4719. Institute for the Study of Labor (IZA), Bonn.

Marschall, Melissa. 2000. The Role of Information and Institutional Arrangements in Stemming the Stratifying Effects of School Choice. Journal of Urban Affairs 22(3): 333-350.

Merzyn, Wolfram, and Heinrich W. Ursprung. 2005. Voter Support for Privatizing Education: Evidence on Self-interest and Ideology. European Journal of Political Economy 21(1): 33-58.

Noreisch, Kathleen. 2007a. Choice as Rule, Exception and Coincidence: Parents' Understandings of Catchment Areas in Berlin. Urban Studies 44(7): 1307-1328.

Noreisch, Kathleen. 2007b. School Catchment Area Evasion: The Case of Berlin, Germany. Journal of Education Policy 22(1): 69-90.

OECD. 2010. PISA 2009 Results: What Makes a School Successful? Paris: OECD Publishing.

Oshio, Takashi, Shinpei Sano, Yuko Ueno, and Kouichiro Mino. 2010. Evaluations by Parents of Education Reforms: Evidence from a Parent Survey in Japan. Education Economics 18(2): 229-246.

Rangvid, Beatrice Schindler. 2010. School Choice, Universal Vouchers and Native Flight from Local Schools. European Sociological Review 26(3): 319-335.

Raveaud, Maroussia, and Agnes van Zanten. 2007. Choosing the Local School: Middle Class Parents' Values and Social and Ethnic Mix in London and Paris. Journal of Education Policy 22(1): 107-124. 
Reay, Diane, Sumi Hollingworth, Katya Williams, Gill Crozier, Fiona Jamieson, David James, and Phoebe Beedell. 2007. "A Darker Shade of Pale?" Whiteness, the Middle Classes and Multi-Ethnic Inner City Schooling. Sociology 41(6): 1041-1060.

Riedel, Andrea, Kerstin Schneider, Claudia Schuchart, and Horst Weishaupt. 2010. School Choice in German Primary Schools: How Binding Are School Districts? Journal for Educational Research Online 2(1): 94-120.

Sandy, Jonathan. 1992. Evaluating the Public Support for Educational Vouchers: A Case Study. Economics of Education Review 11(3): 249-256.

Saporito, Salvatore. 2003. Private Choices, Public Consequences: Magnet School Choice and Segregation by Race and Poverty. Social Problems 50(2): 181-203.

Schmidheiny, Kurt. 2006. Income Segregation and Local Progressive Taxation: Empirical Evidence from Switzerland. Journal of Public Economics 90(3): 429-458.

Sikkink, David, and Michael O. Emerson. 2008. School Choice and Racial Segregation in US Schools: The Role of Parents' Education. Ethnic and Racial Studies 31(2): 267-293.

Tedin, Kent L., Richard E. Matland, and Gregory R. Weiher. 2001. Age, Race, Self-Interest, and Financing Public Schools through Referenda. Journal of Politics 63(1): 270-294.

Vincent, Carol, Annette Braun, and Stephen Ball. 2010. Local Links, Local Knowledge: Choosing Care Settings and Schools. British Educational Research Journal 36(2): 279-298.

Waslander, Sietske, Cissy Pater, and Maartje van der Weide. 2010. Markets in Education: An Analytical Review of Empirical Research on Market Mechanisms in Education. OECD Education Working Papers 52, OECD Publishing, Paris.

West, Martin R., and Ludger Wössmann. 2010. "Every Catholic Child in a Catholic School": Historical Resistance to State Schooling, Contemporary School Competition, and Student Achievement across Countries. Economic Journal 120(546): F229-F255.

Yoon, Ee-Seul, and Kalervo N. Gulson. 2010. School Choice in the Stratilingual City of Vancouver. British Journal of Sociology of Education 31(6): 703-718. 


\section{Appendix}

Table A1 Descriptive representation of variables

\begin{tabular}{|c|c|c|c|}
\hline & $\begin{array}{r}\text { Number of } \\
\text { observations }\end{array}$ & Mean & $\begin{array}{l}\text { Standard } \\
\text { deviation }\end{array}$ \\
\hline Preference for private school choice* & 1933 & 0.27 & 0.45 \\
\hline Preference for public school choice* & 1906 & 0.64 & 0.48 \\
\hline Gender (female)* & 2025 & 0.50 & 0.50 \\
\hline \multicolumn{4}{|l|}{$\mathrm{Age}^{*}$} \\
\hline Age $25-39$ & 2025 & 0.26 & 0.44 \\
\hline Age 40-64 & 2025 & 0.49 & 0.50 \\
\hline Age 65+ & 2025 & 0.25 & 0.43 \\
\hline \multicolumn{4}{|l|}{ Household income* } \\
\hline Below CHF 3000 & 1781 & 0.12 & 0.33 \\
\hline CHF $3000-5000$ & 1781 & 0.26 & 0.44 \\
\hline CHF $5000-7000$ & 1781 & 0.27 & 0.44 \\
\hline CHF 7000-9000 & 1781 & 0.19 & 0.40 \\
\hline Above CHF 9000 & 1781 & 0.16 & 0.37 \\
\hline \multicolumn{4}{|l|}{ Educational attainment* } \\
\hline Lower-secondary education & 2025 & 0.24 & 0.43 \\
\hline Upper-secondary education & 2025 & 0.51 & 0.50 \\
\hline Tertiary education (but not teacher training) & 2025 & 0.22 & 0.41 \\
\hline Teacher training qualification & 2025 & 0.03 & 0.18 \\
\hline \multicolumn{4}{|l|}{ Children* } \\
\hline No children & 2019 & 0.27 & 0.44 \\
\hline Child(ren) at school & 1947 & 0.24 & 0.43 \\
\hline Child(ren), but not at school & 1947 & 0.48 & 0.50 \\
\hline Homeowner* & 2001 & 0.53 & 0.50 \\
\hline \multicolumn{4}{|l|}{ Size of center of population* } \\
\hline Rural community & 2025 & 0.33 & 0.47 \\
\hline Small/medium center of population & 2025 & 0.34 & 0.47 \\
\hline Large center of population & 2025 & 0.33 & 0.47 \\
\hline \multicolumn{4}{|l|}{ Language region* } \\
\hline German & 2025 & 0.69 & 0.46 \\
\hline French & 2025 & 0.25 & 0.43 \\
\hline Italian & 2025 & 0.06 & 0.24 \\
\hline
\end{tabular}


Continuation of Table A1.

\begin{tabular}{lrrr}
\hline & $\begin{array}{c}\text { Number of } \\
\text { observations }\end{array}$ & Mean & $\begin{array}{r}\text { Standard } \\
\text { deviation }\end{array}$ \\
\hline $\begin{array}{l}\text { Political affiliation* } \\
\text { Left }\end{array}$ & 2025 & 0.17 & 0.38 \\
Center & 2025 & 0.49 & 0.50 \\
Right & 2025 & 0.15 & 0.35 \\
Missing & 2025 & 0.19 & 0.39 \\
Supports higher spending on education* & 2014 & 0.65 & 0.48 \\
Proportion of foreigners in place of residence & 2025 & 19.7 & 10.63 \\
Proportion of (non-subsidized) private schools & 2025 & 3.55 & 3.41 \\
\hline
\end{tabular}

* Dummy-variables.

Data: University of Bern, "Public opinion on education in Switzerland" (POES).

Table A2 Bivariate statistics: approval rates for free school choice (in \%)

\begin{tabular}{lrr}
\hline & $\begin{array}{r}\text { Approval rates for } \\
\text { private school choice } \\
(\mathrm{N}=1637)\end{array}$ & $\begin{array}{r}\text { Approval rates for } \\
\text { public school choice } \\
(\mathrm{N}=1612)\end{array}$ \\
\hline $\begin{array}{l}\text { Gender } \\
\text { Male }\end{array}$ & 25.18 & 58.75 \\
Female & 29.89 & 69.02 \\
Age & & \\
Age 25-39 & 23.89 & 69.70 \\
Age 40-64 & 27.72 & 61.38 \\
Age 65+ & 30.69 & 61.88 \\
Household income & & 62.63 \\
Below CHF 3000 & 27.89 & 67.59 \\
CHF 3000-5000 & 31.19 & 63.84 \\
CHF 5000-7000 & 25.23 & 61.54 \\
CHF 7000-9000 & 27.91 & 61.13 \\
Above CHF 9000 & 24.54 & \\
Educational attainment & & 60.37 \\
Lower-secondary education & & 65.73 \\
Upper-secondary education & & 65.00 \\
Tertiary education (but not teacher training) & 26.21 & 48.21 \\
Teaching training qualification & 26.87 & \\
\end{tabular}


Continuation of Table A2.

\begin{tabular}{lrr}
\hline & $\begin{array}{r}\text { Approval rates for } \\
\text { private school choice } \\
(\mathrm{N}=1637)\end{array}$ & $\begin{array}{r}\text { Approval rates for } \\
\text { public school choice } \\
(\mathrm{N}=1612)\end{array}$ \\
\hline Children & 25.45 & 67.57 \\
$\quad$ No children & 30.94 & 66.33 \\
Child(ren) at school & 26.75 & 60.10 \\
Child(ren), but not at school & & 62.46 \\
House ownership & 29.34 & 65.13 \\
Homeowner & 25.26 & 61.62 \\
Tenant & & 61.91 \\
Size of center of population & 25.68 & 67.60 \\
Rural community & 27.64 & 63.81 \\
Small/medium center of population & 28.99 & 61.11 \\
Large center of population & & 75.95 \\
Language region & 30.55 & \\
German-speaking region & 18.87 & \\
French-speaking region & 28.57 & \\
Italian-speaking region & &
\end{tabular}

Data: University of Bern, "Public opinion on education in Switzerland" (POES). 
Copyright of Swiss Journal of Sociology is the property of Societe Suisse de Sociologie / Swiss Sociological Association and its content may not be copied or emailed to multiple sites or posted to a listserv without the copyright holder's express written permission. However, users may print, download, or email articles for individual use. 